\title{
STUDIES ON CEPHRADINE AND ITS COMPOUNDS WITH TIN(II), LEAD(II), MANGANESE(II) AND IRON(II)
}

\author{
Ashu Chaudhary", Anita Phor', G.K. Agarwal' and R.V. Singh"• \\ a Department of Chemistry, University of Rajasthan, Jaipur 302004, India \\ E-mail : kudiwal(@)datainfosys.net \\ ${ }^{b}$ Department of Chemistry, D.J. College, Baraut, Meerut-250617, India \\ 'Hindu College, Sonepat, India
}

\begin{abstract}
New complexes of tin(II), lead(II), manganese(II) and iron(II) with antibacterial cephradine have been isolated and characterized by elemental analysis, IR, Electronic, Magnetic moment, ${ }^{57} \mathrm{Fe}$, Mössbauer, ${ }^{1} \mathrm{H} N \mathrm{NR},{ }^{13} \mathrm{C}$ and ${ }^{119}$ Sn NMR spectral studies. The spectral data suggested hexacoordinated state for these complexes. Conductivity data suggested that they behave as non-electrolytes. The formulation of the complexes of the type $\left[\mathrm{M}(\mathrm{L})_{2} \mathrm{Cl}_{2}\right]$, \{where, $\mathrm{M}=\mathrm{Sn}(\mathrm{II}), \mathrm{Pb}(\mathrm{II}), \mathrm{Mn}$ (II) and $\mathrm{Fe}(\mathrm{II})$ and $\mathrm{L}=$ cephradine showing octahedral geometry. In order to evaluate the effect of metal ions upon chelation, cephradine and its complexes have been screened for their antibacterial activity against Escherichia coli, Staphylococcus aureus and Pseudomonas aeruginosa.
\end{abstract}

\section{Introduction}

The development and design of new products with the potential for the use as biologically active compounds has recently become a burgeoning topic within the biological sciences ${ }^{1-15}$ and chemistry in particular ${ }^{16-19}$. Evidences supporting the introduction of metallic elements in several biological process are rapidly accumulating ${ }^{2(1-22}$. Schubert ${ }^{23}$ and Kirschner ${ }^{24}$ have investigating the antibacterial, antiviral and anticancer activities of more than 25 inorganic compounds, which included the metal atom as potentially significant part of the molecule. They suggested $^{24,25}$ that the transfer of metal ions from the ligand to the cancer-associated viruses was a mechanism for releasing the anticancer drug in the locality of the tumor. Due to the significant nature of the metallic ions. their metal complexes are now, being included in the search for ideal anticancer drugs. Such significant examples of which are palladium and platinum of 6-mercaptopurine that destroy ${ }^{26}$ adenoca, rcinomas and similarly, the complexes of dialkyldithiophosphate which reduce some tumors ${ }^{27}$. A wide range of activities of even the simplest complexes of metallic elements has been reviewed by Rosenberg ${ }^{28}$ who noticed that the viralinduced cancers all respond to the treatment with even the simplest metal-amino halide complexes. It has also been demonstrated that chelation/complexation tend to make inactive substances/ligand active and active compounds/drugs become more active and less toxic ${ }^{29,30}$. All these evidences however, highlight the need to study and evaluate more the biological applications of metallic clements for therapeutic potentials

Cephradine is a first generation cephalosporin class of antibiotic ${ }^{33}$, used against Gram-positive cocci and Gram-negative bacilli. It has similar structural and antibacterial relationship to that of its closely related analogue cephalexin. It contains the $\left(\mathrm{NH}_{2}\right)$. $(\mathrm{COOH}),(\mathrm{NH})$ and $(\mathrm{C}=\mathrm{O})$ functional groups and its molecular model reveals that its structure is suitable for chelation/complexation. A detailed biological evaluation of the copper(II) and zinc(II) complexes of cephalexin has been reported ${ }^{32}$. In order to evaluate the biological comparison of both the analogues, we, therefore, report in this paper the preparation, characterization and

\footnotetext{
*Authors for correspondence Prof. R.V. Singh, Department of Chemistry, University of Rajasthan. Jaipur-302004, India. Fax : +91-141-2708621; E-mail : kudiwal@datainfosys.net
} 


\section{Experimental}

All chemicals and solvents used were of Analar grade. $\mathrm{SnCl}_{2}, \mathrm{PbCl}_{2}, \mathrm{MnCl}_{2} .4 \mathrm{H}_{2} \mathrm{O}$ and $\mathrm{FeCl}_{2} .4 \mathrm{H}_{2} \mathrm{O}$ were used as obtained from B.D.H.

\section{Synthesis of the Complexes}

A methanolic solution $(25 \mathrm{~mL})$ of tin chloride $(0.90 \mathrm{~g} ; 4.7 \mathrm{mmol})$ was added to a magnetically stirred sodium salt of cephradine $(3.31 ; 9.4 \mathrm{mmol})$ in distilled water $(15 \mathrm{~mL})$. The reaction mixture was refluxed for $6 \mathrm{~h}$ and cooled to room temperature. On cooling white precipitate was formed, filtered and washed with methanol and ether, and dried in vacuo. The complex [tin(II) cephradine] was recrystallized in benzene.

All other heterocyclic metal complexes were formed following the same method.

\section{Analytical Methods and.Physical Measurements}

The molecular weights were determined by the Rast Camphor Method. Conductivity measurements were made with a systronic model 305 conductivity bridge in dry dimethylformamide. The IR spectra of the solid samples were recorded as $\mathrm{KBr}$ discs on a Nicoletmagna FTIR 550 spectrophotometer. Electronic spectra recorded on UV-160A, Shimadzu spectrophotometer in the range $200-600 \mathrm{~nm}$ using methanol as the solvent. The ${ }^{1} \mathrm{H}$ NMR and ${ }^{13} \mathrm{C}$ NMR spectra were recorded on a FX $90 \mathrm{Q}$ spectrometer in DMSO- $\mathrm{d}_{6}$ using TMS as the internal standard. ${ }^{119} \mathrm{Sn}$ NMR spectra of the compounds were also recorded on the same spectrometer at $33.35 \mathrm{M} \mathrm{Hz}$.

\section{Results and Discussion}

All these complexes are coloured solids, which do not have sharp melting points. These are decomposed above $215^{\circ} \mathrm{C}$. The conductivity values measured for $10^{-3} \mathrm{M}$ solutions in anhydrous dimethylformamide are in the range 14-21 ohm $\mathrm{om}^{2}$ and $\mathrm{mol}^{-1}$ showing them to be non-electyrolytes. Molecular weights of the complexes indicated the monomeric nature of the complexes. Elemental analyses agree well with the stoichiometry and chemical formula $\left[\mathrm{M}(\mathrm{L})_{2} \mathrm{Cl}_{2}\right]$, where, $\mathrm{M}=\mathrm{Sn}(\mathrm{II}), \mathrm{Pb}(\mathrm{II}), \mathrm{Mn}(\mathrm{II})$ and $\mathrm{Fc}(\mathrm{II})$ and $\mathrm{L}=$ Cephradine. The physical properties and analytical data of the complexes are given in Table 1.

Table 1 - Physical Properties and Analytical Data of the Metal Complexes.

\begin{tabular}{|c|c|c|c|c|c|}
\hline \multirow{2}{*}{$\begin{array}{c}\text { Empirical formula and } \\
\text { M.P. }\left({ }^{\circ} \mathrm{C}\right)\end{array}$} & \multicolumn{4}{|c|}{$\begin{array}{c}\text { Analysis (\%) } \\
\text { Found (Calcd.) }\end{array}$} & \multirow{2}{*}{$\begin{array}{c}\text { Mol. Wt. } \\
\text { Found. (Calcd.) }\end{array}$} \\
\hline & $\mathrm{C}$ & $\mathrm{H}$ & $\mathrm{N}$ & $\mathrm{Cl}$ & \\
\hline $\mathrm{C}_{32} \mathrm{H}_{36} \mathrm{~N}_{6} \mathrm{O}_{8} \mathrm{~S}_{2} \mathrm{SnCl}_{2}$ & 37.5 & 3.4 & 6.7 & 6.9 & 986 \\
\hline 163 & $(37.7)$ & $(3.5)$ & $(8.2)$ & $(7.0)$ & $(1017)$ \\
\hline $\mathrm{C}_{32} \mathrm{H}_{36} \mathrm{~N}_{6} \mathrm{O}_{8} \mathrm{~S}_{2} \mathrm{PbCl}_{2}$ & 34.6 & 2.7 & 6.7 & 5.7 & 1088 \\
\hline 179 & $(34.7)$ & $(2.9)$ & $(7.6)$ & $(6.4)$ & $(1105)$ \\
\hline $\mathrm{C}_{3}, \mathrm{H}_{36} \mathrm{~N}_{6} \mathrm{O}_{8} \mathrm{~S}_{2} \mathrm{MnCl}_{2}$ & 39.8 & 3.6 & 7.4 & 6.8 & 933 \\
\hline 156 & $(40.0)$ & $(3.7)$ & $(8.7)$ & $(7.3)$ & $(961)$ \\
\hline $\mathrm{C}_{32} \mathrm{H}_{36} \mathrm{~N}_{6} \mathrm{O}_{8} \mathrm{~S}_{2} \mathrm{FeCl}_{2}$ & 39.9 & 3.6 & 7.72 & 6.6 & 937 \\
\hline 181 & $(40.0)$ & $(3.7)$ & $(8.7)$ & $(7.3)$ & $(960)$ \\
\hline
\end{tabular}

The IR spectra of the complexes in comparison to the uncomplexed cephradine are listed in Table 2 with some tentative important characteristic assignments ${ }^{23}$. The IR spectrum of the cephradine shows some 
characteristic bands at $3340,3247,1766$ and $1745 \mathrm{~cm}^{-1}$ mainly due to the $v\left(\mathrm{NH}_{2}\right), v(\mathrm{NH}), v(\mathrm{COOH})$ and $v(\mathrm{C}=\mathrm{O})$ vibrations, respectively. The metal complexes also contained other bands indicative of the coordination of the ligand with the metal ions. The band due to $v(\mathrm{COO})$ asym at $1766 \mathrm{~cm}^{-1}$ in the spectrum of the ligand shifted to lower frequency $\left(10-15 \mathrm{~cm}^{-1}\right)$ in all the metal complexes indicative of the complexation ${ }^{34}$. New absorption bands assigned to $v(\mathrm{COO})$ and $v(\mathrm{M}-\mathrm{O})$ appeared at $1566-1577 \mathrm{~cm}^{-1}$ and $419-429 \mathrm{~cm}^{-1}$ which were only observed in the spectra of the complexes. This in tum, indicated that the carboxyl group is coordinated to the metal ion. Also, the band due to $v\left(\mathrm{NH}_{2}\right)$ at $3340 \mathrm{~cm}^{-1}$ was found shifted to lower wave number in the spectra of its metal complexes. A new band at $450-459 \mathrm{~cm}^{-1}$ assigned to $v(\mathrm{M}-\mathrm{N})$ was evolved in the spectra of the complexes indicating ${ }^{35}$ involvement of the $v\left(\mathrm{NH}_{2}\right)$ group via nitrogen in the coordination. In the far infrared region a band at $351-367 \mathrm{~cm}^{-1}$ was found in the complexes assigned to $v(\mathrm{M}-\mathrm{Cl})$ modes. It in turn, suggested that two chloride atoms are also coordinated to the metal atom. These evidences support the octahedral geometry for these complexes.

Table 2 - IR Spectra Data $\left(\mathrm{cm}^{-1}\right)$ of the Metal Complexes.

\begin{tabular}{lcccccccc}
\hline Compound & $v \mathrm{NH}_{2}$ & $v \mathrm{NH}$ & $v(\mathrm{COOH})$ & $v \mathrm{C}=\mathrm{O}$ & $v(\mathrm{COO})$ & $v(\mathrm{M}-\mathrm{N})$ & $v(\mathrm{M}-\mathrm{Cl})$ & $v(\mathrm{M}-\mathrm{O})$ \\
Cephradine & 3340 & 3247 & 1766 & 1745 & - & - & - & - \\
{$\left[\mathrm{Sn}(\mathrm{L})_{2} \mathrm{Cl}_{2}\right]$} & 3537 & 3246 & - & 1743 & 1754,1571 & 459 & 367 & 425 \\
{$\left[\mathrm{~Pb}(\mathrm{~L})_{2} \mathrm{Cl}_{2}\right]$} & 3541 & 3244 & - & 1741 & 1759,1566 & 454 & 351 & 419 \\
{$\left[\mathrm{Mn}(\mathrm{L})_{2} \mathrm{Cl}_{2}\right]$} & 3545 & 3242 & - & 17.40 & 1755,1577 & 450 & 355 & 423 \\
{$\left[\mathrm{Fe}(\mathrm{L})_{2} \mathrm{Cl}_{2}\right]$} & 3529 & 3253 & - & 1737 & 1750,1565 & 452 & 364 & 429 \\
\hline
\end{tabular}

The electronic spectrum of the $\left[\mathrm{Mn}(\mathrm{L})_{2} \mathrm{Cl}_{2}\right]$ exhibited absorption bands at 587,449 and $376 \mathrm{~nm}$ attributed to ${ }^{6} \mathrm{~A}_{1 \mathrm{~g}} \rightarrow{ }^{4} \mathrm{~T}_{\mathrm{lg}},{ }^{6} \mathrm{~A}_{1 \mathrm{~g}} \rightarrow \mathrm{T}_{2 \mathrm{~g}}$ and ${ }^{6} \mathrm{~A}_{1 \mathrm{~g}} \rightarrow{ }^{4} \mathrm{t}_{1 \mathrm{~g}}$, respectively ${ }^{36}$. The electronic spectrum of the [Fe( $\left.(\mathrm{L})_{2} \mathrm{Cl} l_{2}\right]$ display a weak intensity band at $868 \mathrm{~nm}^{37}$. These are found to be consistent with the octahedral geometry for these complexes.

The valucs $\mu \beta$ for the complex $\left[\mathrm{Mn}(\mathrm{L})_{2} \mathrm{Cl}_{2}\right]$ were observed at 5.88 B.M. and are within the range required for an octahedral grometry ${ }^{38}$.

The mössbauer spectrum of the complex $\left[\mathrm{Fe}(\mathrm{L})_{2} \mathrm{Cl}_{2}\right]$ has been recorded. The values of the isomer shift $\left(0.27 \mathrm{~mm}^{-1}\right)$ and quadrupali splitting $\left(0.65 \mathrm{~mm} \delta^{-1}\right)$ at room temperature are characteristic of six coordinated low spin iron complex ${ }^{39}$.

${ }^{1} \mathrm{H}$ and ${ }^{13} \mathrm{C}$ NMR spectra of the uncomplexed cepharadine and its $\left[\mathrm{Sn}(\mathrm{L})_{2} \mathrm{Cl}_{2}\right]$ and $\left[\mathrm{Pb}(\mathrm{L})_{2} \mathrm{Cl}_{2}\right]$ complexes have been recorded in DMSO- $\mathrm{d}_{6}$ with TMS as internal reference and are summarized in Table 3 . The spectra of cephradine exhibited peaks that are expected ${ }^{40}$ for its structure. Signals for the $\mathrm{NH}$ and $\mathrm{COOH}$ protons in the spectra of uncomplexed cephradine at $\delta 10.8 \mathrm{ppm}$ disappeared in the complexes. This indicated that cephradine is coordinated to the metal atom by deprotonation. In the metal complexes the aromatic proton signals appeared downfield due to increased conjugation during coordination ${ }^{41}$ are characteristic of sixcoordinated low spin iron complex ${ }^{39}$. 
Table 3 - 'H NMR and ${ }^{13} \mathrm{C}$ NMR $(\delta$, ppm) Spectral Data of Metal Complexes.

\begin{tabular}{|c|c|c|}
\hline Compounds & ${ }^{1} \mathrm{H}$ NMR (ppm) & C NMR (ppm) \\
\hline Cephradine & $\begin{array}{l}2.1\left(\mathrm{~s}, 6 \mathrm{H}, \mathrm{CH}_{3}\right), 46(\mathrm{~d}, 2 \mathrm{H}, \mathrm{NCH}), 7.1(\mathrm{~m}, 4 \mathrm{H} \\
\mathrm{Ph}, 7.1(\mathrm{~m}, 4 \mathrm{H}, \mathrm{Ph}), 7.4(\mathrm{~m}, 2 \mathrm{H}, \mathrm{Ph}), 8.1(\mathrm{~d}, \\
2 \mathrm{H}, \beta \text {-lactam }) 8.3(\mathrm{~m}, 4 \mathrm{H} \text {, hetero-Ph), } 8.4(\mathrm{~m}, \\
2 \mathrm{H} \text {, hetero- } \mathrm{Ph})\end{array}$ & $\begin{array}{l}13.3\left(\mathrm{CH}_{3}\right), 62.8(\mathrm{CHN}), 117.6(\beta \text {-lactam }), \\
119.6,122.2,124.6(\text { hetero-Ph), } 1482,125.4, \\
127.0,129.1,172.2(\mathrm{C}=\mathrm{O}), 177.2(\mathrm{COO}), \\
211.6(\beta \text {-lactam })\end{array}$ \\
\hline$[\mathrm{Sn}(\mathrm{L}$ & $\begin{array}{l}2.1\left(\mathrm{~s}, 6 \mathrm{H}, \mathrm{CH}_{3}\right), 46(\mathrm{~d}, 2 \mathrm{H}, \mathrm{NCH}), 7.1(\mathrm{~m}, 4 \mathrm{H} \\
\mathrm{Ph}), 7.1(\mathrm{~m}, 4 \mathrm{H}, \mathrm{Ph}), 7.4(\mathrm{~m}, 2 \mathrm{H}, \mathrm{Ph}), 8.1(\mathrm{~d}, \\
2 \mathrm{H}, \beta \text {-lactam }) 8.3(\mathrm{~m}, 4 \mathrm{H}, \text { hetero-Ph), } 8.4(\mathrm{~m}, \\
2 \mathrm{H}, \text { hetero-Ph). }\end{array}$ & $\begin{array}{l}13.3\left(\mathrm{CH}_{3}\right), 62.8(\mathrm{CHN}), 117.6(\beta \text {-lactam }), \\
119.6,122.2,124.6(\text { hetero-Ph), } 1482,125.4, \\
127.0,129.1,172.2(\mathrm{C}=\mathrm{O}), 177.2(\mathrm{COO}), \\
211.6(\beta \text {-lactam })\end{array}$ \\
\hline$[\mathrm{Pb}(\mathrm{L}$ & $\begin{array}{l}2.1\left(\mathrm{~s}, 6 \mathrm{H}, \mathrm{CH}_{3}\right), 46(\mathrm{~d}, 2 \mathrm{H}, \mathrm{NCH}), 7.1(\mathrm{~m}, 4 \mathrm{H} \\
\mathrm{Ph}), 7.1(\mathrm{~m}, 4 \mathrm{H}, \mathrm{Ph}), 7.4(\mathrm{~m}, 2 \mathrm{H}, \mathrm{Ph}), 8.1(\mathrm{~d}, \\
2 \mathrm{H}, \beta \text {-lactam }) 8.3(\mathrm{~m}, 4 \mathrm{H} \text {, hetero- } \mathrm{Ph}), 8.4(\mathrm{~m}, \\
2 \mathrm{H}, \text { hetero- } \mathrm{Ph}) .\end{array}$ & $\begin{array}{l}13.3\left(\mathrm{CH}_{3}\right), 62.8(\mathrm{CHN}), 117.6(\beta \text { lactam}), \\
119.6,122.2,124.6(\text { hetero-Ph), 148.2,125.4, } \\
127.0,129.1,172.2(\mathrm{C}=\mathrm{O}), 177.2(\mathrm{COO}), \\
211.6(\beta \text {-lactam })\end{array}$ \\
\hline
\end{tabular}

The ${ }^{119} \mathrm{Sn}$ NMR spectrum of the $\left[\mathrm{Sn}(\mathrm{L})_{2} \mathrm{Cl}_{2}\right]$ complex gives signal at $\delta-589 \mathrm{ppm}$ indicating coordination number six in the complex around tin atom ${ }^{42}$.

On the basis of the above observations, it is tentatively suggested that all the complexes show an octahedral geometry (Fig.1) in which two cephradine molecules act as bidentate and at axial positions two chlorides are coordinated to the metal atom.

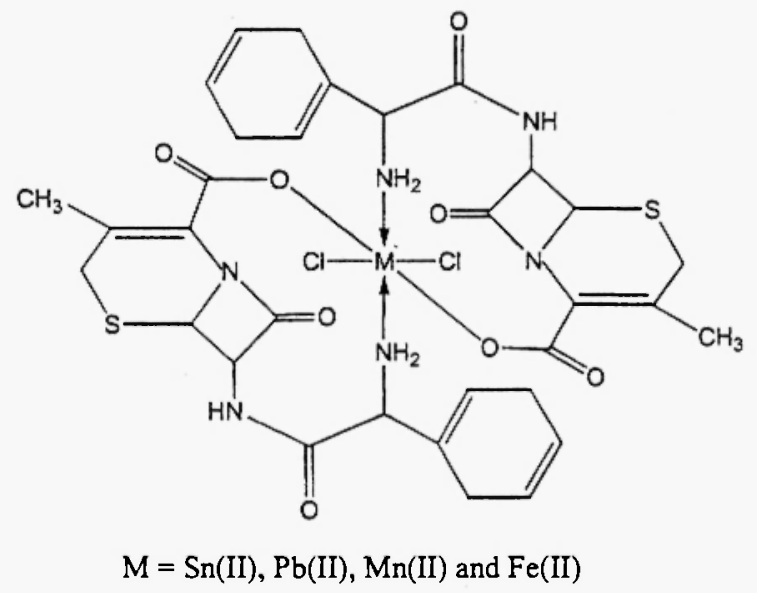

(Fig. 1)

\section{Biological Properties}

Bioefficacies of the synthesized compounds were checked in vitro and in vivo. The in vitro antifungal, activities of the ligands and their complexes have been evaluated against several fungi by the Radial Growth Method ${ }^{43}$. The compounds were directly mixed with the medium in different concentrations. Controls were also run and three replicates were used in each case. The linear growth of the fungus was obtained by measuring the diameter of the fungal colony after four days (Table 4). The amount of growth inhibition in each of the replicates was calculated by :

$$
\% \text { inhibition }=\frac{(\delta c-\delta t) \times 100}{\delta c}
$$

Where $\delta \mathrm{c}$ is the diameter of the colony on the control plate and $\delta \mathrm{t}$ is the diameter of the fungal colony on the test plate. 
The synthesized metal complexes, in comparison to the uncomplexed cephradine were also screened for their antibacterial activity against pathogenic bacterial species, Escherichia coli, Staphylococcus aureus and Pseudomonas aeruginosa. The paper disc diffusion method was adopted for the determination of antibacterial activity. The compounds were tested at a concentration of $30 \mu \mathrm{g} / 0.01 \mathrm{~mL}$ in DMF solution using paper disc diffusion method ${ }^{43}$. The susceptibility zones were measured in diameter $(\mathrm{mm})$ and the results are reported in Table 5. Cephradine and its metal complexes individually were found to be biologically active showing various degrees of inhibitory effect on the growth of the tested bacterial species. The bacterial results evidently show that the complexation improved the antibacterial activity.

Table 4 - Fungicidal Screening Data of Metal Complexes.

\begin{tabular}{|c|c|c|c|c|c|c|c|}
\hline \multirow[b]{2}{*}{ Treatment } & \multirow[b]{2}{*}{$\begin{array}{l}\text { Concentration } \\
(\mathrm{ppm})\end{array}$} & \multicolumn{3}{|c|}{ Alternaria alternata } & \multicolumn{3}{|c|}{ Fusarium oxvsporum } \\
\hline & & $\begin{array}{c}\mathrm{R}_{\mathrm{I}} \\
\text { (angular } \\
\text { value) }\end{array}$ & $\begin{array}{c}\mathrm{R}_{2} \\
\text { (angular } \\
\text { value) }\end{array}$ & $\begin{array}{c}\mathrm{R}_{\mathbf{3}} \\
\text { (angular } \\
\text { value) }\end{array}$ & $\begin{array}{c}\mathrm{R}_{\mathrm{l}} \\
\text { (angular } \\
\text { value) }\end{array}$ & $\begin{array}{c}\mathbf{R}_{\mathbf{2}} \\
\text { (angular } \\
\text { value) }\end{array}$ & $\begin{array}{c}\mathrm{R}_{\mathbf{3}} \\
\text { (angular } \\
\text { value) }\end{array}$ \\
\hline \multirow{4}{*}{$\mathrm{Sn}(\mathrm{L})_{2} \mathrm{Cl}_{2}$}$]$ & 25 & 45 & 43 & 38 & 46 & 39 & 40 \\
\hline & & $(42.13)$ & $(40.98)$ & $(38.06)$ & $(42.71)$ & $(28.65)$ & $(39.23)$ \\
\hline & 50 & 54 & 53 & 51 & 52 & 55 & 52 \\
\hline & & $(47.29)$ & $(46.72)$ & $(45.57)$ & $(46.15)$ & $(47.87)$ & $(46.15)$ \\
\hline \multirow{4}{*}{$\mathrm{Pb}(\mathrm{L})_{2} \mathrm{Cl}_{2}$}$]$ & 25 & 35.0 & 39 & 40 & 34 & 35 & 39 \\
\hline & & $(36.27)$ & $(28.65)$ & $(39.23)$ & $(35.67)$ & $(26.27)$ & $(38.65)$ \\
\hline & 50 & 48 & 52 & 50 & 46 & 50 & 51 \\
\hline & & $(43.85)$ & $(46.15)$ & $(45.00)$ & $(42.71)$ & $(45.00)$ & $(45.57)$ \\
\hline \multirow{4}{*}{$\mathrm{Mn}(\mathrm{L})_{2} \mathrm{Cl}_{2}$}$]$ & 25 & 46 & 48 & 50 & 39 & 42 & 43 \\
\hline & & $(42.71)$ & $(43.85)$ & $(45.00)$ & $(28.65)$ & $(40.40)$ & $(40.98)$ \\
\hline & 50 & 55 & 56 & 54 & 54 & 55 & 54 \\
\hline & & $(47.85)$ & $(49.02)$ & $(47.29)$ & $(47.29)$ & $(47.87)$ & $(47.29)$ \\
\hline \multirow{4}{*}{$\mathrm{Fe}(\mathrm{L})_{2} \mathrm{Cl}_{2}$}$]$ & 25 & 41 & 39 & 40 & 37 & 38 & 35 \\
\hline & & $(39.82)$ & $(38.65)$ & $(39.27)$ & $(37.46)$ & $(38.06)$ & $(36.27)$ \\
\hline & 50 & 52 & 53 & 54 & 52 & 45 & 50 \\
\hline & & $(46.15)$ & $(46.72)$ & $(47.29)$ & $(46.15)$ & $(42.13)$ & $(45.00)$ \\
\hline
\end{tabular}

Table 5 - Antibacterial Screening Data of the Cephradine and its Metal Complexes.

$\begin{array}{cc}\text { Escherichia coli Staphylococcus aureus } & \begin{array}{c}\text { Pseudomonas } \\ \text { aeruginosa }\end{array}\end{array}$

\begin{tabular}{lccc}
$\left.\left[\mathrm{Sn}(\mathrm{L})_{2} \mathrm{Cl}_{2}\right)\right]$ & ++++ & +++ & +++ \\
$\left.\left[\mathrm{Pb}(\mathrm{L})_{2} \mathrm{Cl}_{2}\right)\right]$ & +++ & +++ & +++ \\
$\left.\left[\mathrm{Mn}(\mathrm{L})_{2} \mathrm{Cl}_{2}\right)\right]$ & ++ & ++ & ++ \\
$\left.\left[\mathrm{Fe}(\mathrm{L})_{2} \mathrm{Cl}_{2}\right)\right]$ & +++ & ++ & +++ \\
Cephradine & ++ & + & ++ \\
\hline
\end{tabular}

Inhibition zone diameter $\mathrm{mm}$ (\% inhibition) :

$+=6-10(27-45 \%), \quad++=10-14(45-64 \%), \quad+++=14-18(64-84 \%), \quad++++=18-22(82-100 \%)$

Percentage inhibition values are relative to inhibition zone $(22 \mathrm{~m})$ with $100 \%$ inhibition.

Acknowledgement

One of the authors (AC) is thankful to CSIR New Delhi for financial assistance in the form of SRF vide Grant No. $9 / 149(288) / 2 \mathrm{~K} 2$, EMR-1. 


\section{References}

1. William AJP Bioinorganic Chemistry. American Chemical Society, Washington, DC 1971.

2. Brown DH, Smith WE, Teape JW and Lewis AJ, J Med Chem, 23, 729 (1980).

3. Sharma $\mathrm{K}$ and Singh RV, Met Based Drugs, 1, 7 (2000).

4. Pandey $T$ and Singh RV, Met Based Drugs, 7, 7 (2000).

5. Mastrolorenzo A and Supuran CT, Met Based Drugs, 7, 49 (2000).

6. Scozzafava A and Supuran CT, J Med Chem, 43, 3677 (2000).

7. Scozzafava A, Menabuoni L, Mincione F, Mincione G and Supuran CT, Bioorg Med Chem Lett, 11, 575 (2001).

8. Supuran CT, Scozzafava A, Menabuoni L, Mincione F, Briganti F and Mincione G, Met Based Drugs, 6, 67 (1999).

9. Supuran CT, Minicone F, Scozzafava A, Briganti F, Mincione $G$ and Ilies MA, Eur J Med Chem, 33, 247 (1998)

10. Supuran CT, Scozzafava A, J Enzyme Inhib, 12, 37 (1997).

11. Supursan CT, Scozzafava A, Saramet I and Banciu BD, J Enzyme Inhib, 13, 177 (1998).

12. Minicione G, Scozzafava A and Supuran CT, Met Based Drugs, 4, 27 (1947).

13. Scozzafava A and Supuran CT, Met Based Drugs, 4, 19 (1997).

14. Crowe AJ, In Metal Base Antitiumor Drugs, Vol. I. Gielen, M (ed.). Freund (London) 1988.

15. Seven MJ and Johnson LA, Metal Binding in Medicine, $4^{\text {th }}$ ed. Lippincott Co. P.A. Philadelphia, 1960.

16. Walsh C, Science, 409, 226 (2001).

17. Singh RV, Synth React Inorg Met Org Chem, 21, 16 (1986).

18. Clemenson PI, Coord Chem Rev, 106, 171 (1990).

19. McCleverty J, Prog Inorg Chem, 10, 49 (1968).

20. Sigel $\mathrm{H}$ and McCormick DB, Accts Chem Res, 3, 201 (1970).

21. Williams DR, "The Metals of Life", Van Nostrand (London) 1971.

22. Sanders EG, Wright LD and McCormick DB, J Biol Chem 240, 3628 (1965).

23. Schubert J, Sci Amer, 214, 40 (1966).

24. Kirschner S, Kravitz SH and Mack J, J Chem Documentation, 6, 213 (1966).

25. Kirschner S, Wei YK, Francis D and Bergman D, J Med Chem, 6, 369 (1966).

26. Livingstone SE and Nolan JD, Inorg Chem, 7, 1447 (1968).

27. Livingstone SE, Nolan JD and Mihkelson AE, Inorg Chem, 9, 2545 (1970).

28. Rosenberg B, Plat Met Rev, 15, 42 (1971).

29. Nagar $R$ and Mohan $G$, J Inorg Biochem, 42, 9 (1991).

30. Oga S, Taniguchi SF, Najjar R and Souza AR, J Inorg Biochem. 41, 45 (1991).

31. Mahler HR and Cordes EH, 'Biological Chemistry', Harper and Rowe (New York) 1966.

32. Iqubal MS, Ahmad AR, Sabir M and Asad SM, J Pharm Pharmacol 51, 371 (1999).

33. Bellamy LJ, "The Infrared Spectra of Complex Molecules", $3^{\text {rd }}$ Ed, Methuen (London) 1966.

34. Yongxiang $M$, Zhengzhi $Z$, Yun $M$ and Gang Z, Inorg Chim Acta, 165, 185 (1989).

35. Nakamato K, "Infrared Spectra of Inorganic and Coordination Compounds", $2^{\text {nd }}$ Ed, Wiely Interscience (New York) 1970.

36. Patel MN and Patel VJ, Synth React Inorg Met-Org Chem, 19(2), 137, (1989).

37. Baker AT, Singh P and Vigncvich V, Aust J Chem, 44, 1041 (1971).

38. Lal RS, Kumar A and Chakraborty J, Indian J Chem, 40A, 422 (2001).

39. Goodwin HA, Coord Chem Rev, 18, 314 (1976).

40. Dunn G, J Antibiot, 29, 65 (1976).

41. Hong-Yum Z, Dong-Li C, Peikun C, De-ji C, Guang-Xia C and Hong-Quan Z, Polyhedron, 11, 233 (1992).

42. Bansal A, Fahmi N and Singh RV, Appl Organomet Chem, 7, 655 (1993).

43. Sharma K, Fahmi N and Singh RV. Appl Organomet Chem, 15, 221 (2001).

\section{Received on July 9, 2003.}

